Article

\title{
The Ideal of a Radical Christian Intellectual
}

\author{
William Hogue \\ Department of History, Fordham University, New York, NY 10458, USA; whogue@fordham.edu
}

Received: 14 July 2018; Accepted: 12 September 2018; Published: 14 September 2018

\begin{abstract}
The life and work of Ignacio Ellacuría, S.J. is of radical vision and revolutionary change. His dynamic life and works accompanied El Salvador and the Universidad Centroamericana through perhaps the most tumultuous years of the country's history, yet there has been limited work done to examine his contributions. This paper shows how Ellacuría viewed the role of a Christian intellectual and Christian university within his philosophical and theological framework. I argue that Ignacio Ellacuría held, similarly to his soteriological views, that the intellectual must also be willing to sacrifice all for the sake of her/his work in a pattern of discipleship/martyrdom that is prefigured by his exemplars Christ and Socrates. It was this dedication to praxis and theory that western theology and philosophy had respectfully lost since their foundations, which he sought to restore to a central role. In conclusion, the Christian intellectual and institution, according to Ellacuría, must use its voice and life in service of the people even to the point of martyrdom; he would argue, the implicit reason for Christian martyrdom and the crucifixion of Christ himself.
\end{abstract}

Keywords: Ellacuría; liberation theology; El Salvador; Catholicism; Central America; philosophy; martyrdom; Catholic Education; Jesuits; UCA

"The Ideal of a Radical Christian Intellectual" will examine the thought of Ignacio Ellacuría, how he saw the role of the intellectual and university in El Salvador, and what challenges that poses for a liberation oriented academic and university. I argue that his ideal for an intellectual is inextricable from his dual philosophy and theology of martyrdom best expressed through Socrates and Christ, and that the Christian intellectual must be willing, under extreme conditions, to sacrifice all. It was Ellacuría's belief that this was the best way of being a teacher-particularly during the violence and civil war in El Salvador during the 1970s and 80s. While there were difficult questions that he faced as to his loyalty to the Salvadoran people, regardless of his status as an outsider, he attempted with his life to prove that he had an organic interest in the people of El Salvador, not as an ivory tower isolated academic, but as a committed Socratic dedicated to the liberation of the people he felt to be part of. To fully appreciate his view of the role of intellectuals—and, by extension, himself-one must examine his theology, his philosophy, his work as a public intellectual at the Universidad Centroamericana José Simeón Cañas (UCA), and his assassination. Currently, with mounting pressures and violent government-sponsored paramilitary attacks against the UCA in Managua, which is still guided by the mission of "a preferential option for the poor", and "social projection" that Ellacuría and his Jesuit university espoused, it seems timely and critical to assess his views of the role of an intellectual, and the university that he shaped. These questions can also bring us closer in understanding why these Jesuit-Christian universities from a liberation tradition have been targets of state violence.

Ellacuría's close friend and colleague, Jon Sobrino, relates that when he would teach his course on the Historical Jesus of Nazareth, he would become visibly moved with a tremor in his voice speaking of a man who was killed at the hands of the state for speaking the truth, Jesus of Nazareth; who because of his allegiance to the truth, to the poor, and to their liberation was killed in a violent death-he would conclude "a great man". It was that passion so evident in his teaching that shaped his radical pedagogy and his view of the role of the university. The assassination of Ignacio Ellacuría, his Jesuit 
companions, their housekeeper and her daughter draws painful parallels to the life and death of Jesus, however, for Ellacuría, there was a similar paragon who came to illumine minds, and was killed for his teachings as well. Just as Padre Ellacuría came to view the world and his work through the dual lens of philosophy and theology through the "philosophy of historical reality" that shaped his Liberation Theology, his exemplars reflected these principles just as well. Ellacuría would channel these two as the accessible classical examples of what it meant to be an intellectual, and what the message of the university should be: Socrates and Christ. More than anyone else, in his view, these examples were grounded and invested personally in their communities, willing to break down the walls of division and political repression, and willing to risk breaking unjust laws to give their message to the people were his inspiration for his role in the society.

Ignacio Ellacuría S.J. was born 9 November 1930 in Portugalete, in the Basque region of Spain. He entered the Society of Jesus in 1947 at the age of 17 and was sent to El Salvador in 1948. He lived and worked in El Salvador for most of the rest of his life, gaining Salvadoran citizenship. From 1962-1965, Ellacuría worked on his doctorate studying under Spanish philosopher Xavier Zubiri, writing a lengthy dissertation on his concept of "historical reality" which was to unite metaphysics with modern science. In addition, he studied under the great Jesuit theologian Karl Rahner, completing all the coursework to attain a second doctorate, but did not write a second thesis. These men were arguably the two most influential to his academic writings, but while he referenced their concepts and ideas, Ellacuría took inspiration from others as an intellectual and individual. This knowledge of the work of Zubiri and Rahner, in addition to Hegel, Marx, and many important philosophers were critical to the development of his philosophy, and theology of salvation (soteriology). These beliefs would stay with him in theory and praxis as he became an extremely influential public intellectual, connecting the Jesuit universities of Central America through his rectorship at the UCA, his creation of the premier Central American critical journal, mediating political debates, and speaking out around the world against the violence in El Salvador.

This renowned European past would be fortunate for him but raised suspicion of allegiance among his fellow Salvadorans. Theresa Whitefield would note: "Ellacuría would answer criticisms-and they were frequent- that he was a foreigner meddling in the internal affairs of El Salvador by reminding his critics that not only had he been the holder of Salvadoran nationality for many years, but that he had first arrived in the country as a boy of nineteen. By the late 1980s, forty years of dedication to the people of El Salvador, twenty of them in the face of revolution and war, gave him, as it gave his generation of Jesuits, both the historical credibility and the moral authority that are necessary for their voices to be heard, if not always headed" (Whitfield 1995, p. 208). He was often criticized for not doing enough at the grassroots level, and for neglecting to emulate other priests that dedicated time in the base communities and worked with people interpersonally. Many saw him as bourgeois, and his intense commanding personality often reinforced this belief. He also had an innate desire to debate, and to leave those debates a winner, often succeeding. This led to additional criticisms of Padre Ellacuría as arrogant. However, even though Ellacuría was highly cerebral, and spent much less time with the peasants than some of his fellow Jesuits-one thing is certain: that he took great risks to ally himself and the university with the needs of the impoverished, and he did so fully. He said on several occasions that his calling was not among the people and that he did not have those gifts. Whitfield would go on to say: "Cerebral, cool, and critical, Ellacu's guard rarely came down, but when it did it was to show the passion and commitment that lay beneath the rational constructions of his intellect and fueled his extraordinary capacity to keep on going to live in El Salvador creatively, constructively, and with Christian hope" (Whitfield 1995, p. 209). His fellow Jesuits often questioned him as well for his confident intellect and academic career in Spain. When César Jerez teased him, saying "be careful of Ellacuría he'll get you in a whole lot of trouble, and when you get into a lot of trouble, he'll up and off to Spain!" Ellacu responded with "Gordito the only thing I can say is that I am with you to the death" (Whitfield 1995, p. 209). 
His intensive writings on the poor and marginalized "crucified people", and his willingness to put his own and the university's political interests behind them and for their liberation and "social projection" illustrates the personal stake he took in the needs of the Salvadoran people. It must be said that Ellacuría moved closer to this direction over time, and that the witness of the death of Monseñor Romero (1980), and the coincidental popular movements and civil war were one of the last great influences on Ellacuría and his thought (Whitfield 1995, p. 209). It was a testament of his compassion, a side which often went unseen, but which was remembered fondly. Jon Sobrino would write: "Perhaps the most important thing I learned from him as a human being, as a Christian, and a Jesuit, was how to look at the reality of the third world through God, and how to act on this reality with the mercy-justice in structural language—of the heart of God" (Whitfield 1995, p. 210). Despite not being directly involved with the people interpersonally, Ellacuría effectively placed a target on his own head. This was something that he was bitterly aware of since the death of Romero when the government called for the death of all the Jesuit priests in the country. This awareness, indeed this "sacrifice" was central to his philosophy and theology as we see in the development of his theology of salvation and discipleship (soteriology). Even his largest critics were unable to criticize his willingness to fight until the end saying: "Your best argument now is your blood ... Before some of us didn't believe you much. We used to say that you spoke from within the UCA's air conditioning. Now you've got your hands dirty, you've humbled yourself like your master and emptied your strengths and the remains of your pride in the earth that's the same for all of us. Now your Father will hear your priestly prayer" (Whitfield 1995, p. 214).

It is impossible to understand how Ignacio Ellacuría saw himself in the Salvadoran conflict, or society at large without understanding his most revelatory and challenging theology: his views on Christian soteriology. As Michael Lee notes, it is crucial to understand Ellacuría's sense of Christian behavior, which he refers to as 'discipleship', to understand Christianity's fundamental message of salvation in Christ. As he writes: "For in soteriology, one deals both with Christ's redemptive act and the believer's reception of that gracious offer-a reception that involves faith and action" (Lee 2005, p. 22). That is to say, in part, that the disciple of Jesus may have to be willing to lay down his life- "Greater love hath no man than this, that a man lay down his life for his friends" (John 15: 13). But, this sacrifice is not arbitrary or in vain, but fundamentally connected to the teachings, and what Ellacuría calls "historical reality" of the life of Jesus of Nazareth. Lee finally notes that "For clearly, Ellacuría's thought and life demonstrate that the transformation called by discipleship may require the ultimate testimony, a martyr's death" (Lee 2005, p. 29). Indeed, the interconnected inextricable nature of the teachings and discipleship of a Christian, the passion and death of Christ were the most fundamental part of understanding Ellacuría's idea of his role, the role of every Christian in his situation, and it must be understood to understand his behavior in Salvadoran society. As Ellacuría wrote "Jesus does not preach an abstract or purely earthly Kingdom of God, but a concrete Kingdom, which is the contradiction of a world structured by the power of sin; a power that goes beyond the heart of man and becomes historical and structural sin. In these historical conditions, contradiction is inevitable, and the death of Jesus becomes a historical necessity" (Ellacuría [1977] 2000).

The soteriology of Ignacio Ellacuría's liberation theology is rather complicated, due, in part, to a process of disabusing elements of Christian thought since the time of Constantine, which established a shift in Christian theology toward a theology of the ruling elite. So, to understand the landscape of Ellacuría's theology, there is an important philosophical element that must be discussed: his Zubirian understanding of "historical reality". For Zubiri and Ellacuría, a central problem in Western philosophy was that it created a division between sense and the intellect which they found to be disastrous for two reasons. Firstly, in their way of thinking, they said that intellect could only arrive at concepts as it is divorced from reality, and secondly, reality itself becomes reduced to something without dynamism (Ellacuria and Lee 2013, p. 5). Ellacuría acknowledges that "meaning", "being", and "existence" all emerge from reality, while maintaining that this reality also has a materiality. He states that concepts are historically conditioned, and "cannot, in fact do not, remain in the abstract realm 
of ideas". (Ellacuria and Lee 2013, p. 6). His philosophy, "open materialism," was one that that views reality as "dynamic open ended and transcendental" (Ellacuria and Lee 2013, p. 6). So, since reality under his definition was something that encompassed more than what other scholars may view as the strictly empirical or materialist understanding of the state of being, Ellacuría's philosophy of historical reality allowed for philosophical and spiritual components of individuals and societies to be incorporated into the situation at hand. In theology then, as Lee notes, "his most important step was overcoming the dualisms that reduced faith, God, Grace, and salvation to private concepts divorced from history and removed from the challenge of the Gospel" (Ellacuria and Lee 2013, p. 6).

For Ellacuría, once the dualistic nature of neo-scholastic Catholicism had been overcome, this historicism could be applied to the life of Jesus and the nature of his death. Kevin Burke S.J. illustrates this problem in his book, The Ground Beneath the Cross:

"From Ellacuria's perspective, the key dangers arise when the cross is separated from the crucified in such a way that it appears as an abstract, idealized or de-historicized symbol for negativity in general. More pointedly, serious problems emerge when the cross is separated from the act of crucifixion and the fact that specific persons did the crucifying. These dangers are real, not merely speculative. They can be encountered in history today, where innocent victims suffer ten thousand versions of "crucifixion" at the hands of historically real and guilty crucifiers. If theology wants to encounter the cross of Jesus, it must encounter the historical reality-the ground-beneath the cross. If theology wants to discover the Crucified Christ, it must uncover the crucified people". (Burke 2000, p. 175)

The problem of the cross, or more generally, martyrdom, for Ellacuría, must be fundamentally historicized to understand the reality of why Jesus was killed. Indeed, often in standard Christian theology the death of Jesus is couched in a prophetic and metaphysical necessity. Whether it is an historical fulfillment of the prophecy of Isaiah, the "New Adam", or a fulfillment of Abraham's willingness to sacrifice Isaac, or the mere necessity for a perfect sacrifice-all inherently disconnected from the mission and teaching of Jesus and his allegiance to the marginalized and impoverished. Indeed, a favorite phrase of Ellacuría's was "Let us not ask why Jesus died, but why he was killed" (Ellacuria and Lee 2013, p. 8). For Ellacuria's soteriology and concept of discipleship, it was important to examine the society in comparisons with the teachings of Jesus of Nazareth.

The primary importance of the death of Christ, for Ellacuría, was who he had been preaching against, and who he-according to believers-was to redeem. Much of his preaching and actions were focused against the Roman Empire who it was expected the messiah would redeem the Jews from-much like the Exodus from Pharaoh in Egypt. So, while Christian theology has historically fixated on the still important oppositions that Jesus maintained with the Jewish elite and his breaking down of barriers between ethnically and ritually unclean persons, such as Samaritan women and lepers, they rarely focus on the liberation from Roman occupation, which would have been the obvious factor for Judeans of Jesus' time. Ellacuría writes, "Jesus was not killed because of the confusion of his enemies. Neither the Jews nor the Romans were confused, because the action of Jesus, pretending to be primarily an announcement of the Kingdom of God, was necessarily a threat against the established social order" (Ellacuría [1977] 2000). But, the political element of the death of Christ has been historically underdeveloped in Christian theology—in part due to antisemitism, and the affinity of Western authors for preserving Roman traditions, laws, and culture. However, Ellacuría focuses on this Roman Imperial oppression as a key element of the passion and culmination of the teaching of Christ. As Jesus said, "Truly I tell you, today you will be with me in paradise" to the thief on the cross (Luke 23: 43), Ellacuría considers the importance of the symbol of the cross-the symbol of Roman persecution-as the symbol of liberation from Roman oppression as was its original subversive intent for many early Christians.

The crucified people are the final and most critical element of Ellacuría's soteriology and the linking force among his concepts of discipleship, martyrdom, and oppression. Indeed, the relationship 
of Jesus with the people who surrounded him, the people he spoke to, and claimed to represent, was, according to Ellacuría, one win that they became unified in the death on the cross. His last words to the man on the cross, the freeing of Barabbas, and the entire historical reality of the cross as a symbol of the brutality and oppression of Roman imperialism connected Jesus with the most marginalized sectors of his society-those with whom he was already associated. How the crucifixion prefigures the concept of Christian martyrdom, this relationship with the crucified people, the lowest stratum of Roman imperial society, was the key factor in the conspiracy and murder of Christ at the hands of Pilate. Ellacuría wrote: "Both the historical character of the salvation of Jesus and the saving character of the history of the crucified humankind are clarified, once it is accepted that in Jesus salvation is given, and in humankind this salvation is realized" (Ellacuria and Lee 2013, p. 197). Jon Sobrino, his friend and fellow Jesuit intellectual would summarize it well:

"Looking back, thinking about Ellacuria the theoretician, the Rahnerian the Zubirian, one who knew and appreciated some of the contributions of Marxism, tireless seeker of rationality, I believe that his only really unchangeable historical truth during the many years of searching, his sole existential 'dogma', so to speak was the reality of the crucified people and the requirement to take them down from the cross". (Aquino et al. 2006, p. 18)

This was, it would seem his most important mission, and how he saw himself, and, indeed, the Christian in the society—even during a civil war in El Salvador. He was uniting himself-as he saw was his Christian duty and an essential part of discipleship, to the cause of the marginalized and the suffering. He found this proclamation of the "Kingdom of God", as he often referred to the public ministry of Jesus, to be the most essential part of his life and mission. As a fellow Jesuit recalls, "When he was asked to rest, Ellacuría responded that the people did not get rest from the war, nor from poverty" (Lee 2005, p. 21). It is well to remember the teachings of the Second Vatican Council, and Medellin that the Catholic Church has an obligation towards the "preferential option for the poor", Ellacuría takes this a step further, making union with the poor, and sacrifice to the point of death part of the innate nature of Christian discipleship.

While all of this relates directly to theology, I believe that Ellacuría understood his concept of "disciples" (Latin: discipuli) even beyond the range of theology or of Christianity. While, as a priest, Christianity informed his worldview and the nature of much of his writings, he was not a man to neglect the reality of the world, nor of pluralism, nor agnosticism or atheism. In fact, he corrected gurrilla commanders on their knowledge of Marx, and held conversations with people from many walks of life. Indeed, the same method of teaching and discipleship was to be found in another great secular philosophic hero of his-Socrates himself. It seems fitting with the twofold theological and philosophical nature of the writings of Ellacuria, that he would have two foundational witnesses (Greek: $\mu \alpha \dot{\rho} \tau v \sigma$, mártys), martyrs of the quest for "truth" to set as examples of the role of the intellectual in society. As Ellacuría would have considered his teacher and collaborator Zubiri: "The obligation of his life, the sweet and costly obligation, was to pour himself out investigating the truth of those things that appear to be the fundamentals of human life. Like Socrates whom he so admired, Zubiri wanted to convert philosophy itself into an authentic way of life to make of theory a true mode of existence" (Burke 2000, p. 31). It is evident how well the life of Socrates and the life of Christ can seem to mirror one another, both deeply attached to the people of their community, committed to their notions of truth, posing inconvenient opinions and gathering a following, and then conspired against by the powers of their communities, charged with blasphemy and "corrupting the youth" and sentenced to death. As Zubiri and Ellacuría saw it, the role of the intellectual was to be willing to sacrifice all as Socrates, the father of philosophy had, and to move the ivory tower to which academia has been relegated to the needs of the people. So, allegiance to the disenfranchised and most marginalized is following the tradition of Socrates. Jon Sobrino again recalls:

"Doing theology for the purpose described above is, first of all, an expression of the Socratic dimension of the intellectual task, that is, facing up to reality in order to transform it and 
its dominions in order to combat them. As in the case of Socrates, Ellacuria's martyrdom shows there is a way of using intelligence for the purpose of directly influencing reality, really transforming persons and structures". (Aquino et al. 2006, p. 21)

It was this dedication to influencing the society around him, his ability to make people think about the human condition, and the condition of their lives and their poverty, and to take action that was so like Socrates. As Ellacuría wrote, "[Socrates] was a philosopher because he was a citizen, this is because he was political, because he was deeply interested in the problems of his city, his State" (Ellacuría [1976] 1998). While the criticism would still stand that he was not involved in the everyday lives of the poor and those engaged in war, Ellacuría sought to create a space where the exchange of ideas would take place freely, and he sought himself to be an intermediary and a moral voice. Jon Sobrino said that Ellacuría demanded objectivity from the intellectual so that they could clearly see the national reality (Aquino et al. 2006, p. 6). Ellacuría and his fellow Jesuits were willing take a great risk so that there would be a place of objectivity while still holding on to the preferential option for the poor and an allegiance with those who were fighting oppression. This place was their own Universidad Centroamericana (UCA), and the reforms that took place there took great risk and worked to make clear the issues of the time and engaging in a Socratic dialectic with all members of the society.

The UCA under the rectorship of Ignacio Ellacuría witnessed a profound change and became one of the leading voices of reason in El Salvador since the death of Monseñor Romero. There had, since the UCA's founding, been two main types of education in San Salvador, there was the very large public university which was often considered-and in many ways was-a bastion of Marxist thinking, producing many of the thinkers who would comprise various segments of the Salvadoran left. Then, on the other side, was the Jesuit UCA which served to educate the Salvadoran elite's children in a classic private Jesuit school setting. This all changed in the first two years of the 1970s when Fr. Ellacuría deigned to transform the UCA into a "different kind of university". He said that the university "had a very clear idea of what it has to do ... more than mold students, more than carry out research-although we do those two things—what the university has to do is set about solving the unacceptable problem of injustice in the countries throughout Central America" (Whitfield 1995, p. 2). He took the words of the Second Episcopal Conference of Latin America to the university in applying a "preferential option for the poor", and a goal of "social projection" to the university mission. The UCA then began to accept students on a sliding scale-paying according to their ability. This would pose a radical shift from a university that was largely financed by and served the Salvadoran political, economic, and military elite as the university would now focus on the needs of peasants who had for so long been repressed violently by the government. Indeed, after the decision to alter the ethos of the university, most of the Salvadoran elite pulled their funding and children from the university. In turn, a large number of faculty, unable to cope with the cut in pay or disillusioned with change in the country left and took positions elsewhere. Despite the staggering odds and the almost immediate death threats that the Jesuits received, they maintained this mission, and nonetheless established the most prestigious scholarly journal in Central America with a bare bones faculty and very little funding, but with the wholehearted commitment of the Jesuits and faculty.

Even while the university was struggling in its early years, Ellacuría and his Jesuit brothers managed to create the premier journal of Central American studies, Estudios Centroamericanos (ECA), and promote social change. It was through the journal and the institutes at the UCA that the Jesuits were able to promote much of their "proyección social". In ECA issues such as the land ownership system, low wages for peasants, vocational education, and development were addressed (Beirne 1996, p. 101). This was a breakthrough moment where the UCA showed its ability to conduct serious research on the "national reality" (as Ellacuría referred to the situation in El Salvador) and in a way that supported the needs of the people. Not did the journal provide research to support the Salvadoran people, but in solidarity with direct actions like the teachers strike, support for the Jesuit High School, as well as a meeting place for peasant organizations and political debate. 
The UCA set out to transform the reality that it saw to be so unjust, and to engage in dialogue with the popular majorities and the upper echelons of Salvadoran society. At the very beginning Ellacuría sought to reform the physical structure of the university, which he saw to be "proper to a bourgeois mentality at the service of bourgeois mentalities" (Whitfield 1995, p. 233). But, where Ellacuría desires the UCA to go, to a necessary place of social criticism, is reflective of his Socratic methodology. He required the university to be reflective of "historical reality", but it still maintained a place of privilege, which gave it leverage. Sobrino writes: "It is unrealistic to think that a university could be physically in the world of the poor but it is necessary that it sees the world from the perspective of the poor, and that this world enters into its mind and its heart" (Whitfield 1995, p. 247). Ellacuría would refer to this blending of the classical university with the needs of the popular majorities as the "university mystique". The Salvadoran elite, who felt betrayed by the conversion of the UCA, would now monitor everything they did closely and target the Jesuits as one of the main targets throughout the civil war. The Jesuits were perhaps not as monolithic as the military would have believed, but their relationship with the popular majorities was enough to gain their opposition. Just as Socrates, the university often had things to say, which, according to Ruben Zamora were "things that nobody else would say and precious few wanted to hear" (Whitfield 1995, p. 241). It was not only the right-wing military junta, but also the FMLN (Farabundo Martí National Liberation Front) and other leftist organizations could not always distinguish the position of Ellacuría and the university. They would often call into question leaders of the military, but they would also question the activities and abuses of the Left. Perhaps the most famous instance of this is when Ellacuría secured the release of President Duarte's daughter from FMLN hands (indeed aware of the repressive right-wing backlash her death would bring). Just as Socrates was the inconvenient voice of reason, so too did Ellacuría see himself.

Ellacuría saw that there needed to be critical space between the intellectual and the institution and the matters of politics and society. When multiple requests came forward requesting the UCA be the official head of the Christian Democratic Party, before the election of Duarte, the rector insisted that that would not work. Ellacuría was also concerned about the lack of boundaries between the institutional Church/Christian Base Communities and peasant organizations and unions like FECCAS (Gould 2015, p. 290). While some saw no problem in having the peasant worker organizations headquartered in the university, Ellacuría was emphatically against it. Even when groups would schedule meetings at the UCA, Ellacuría would insist that most of the conversation be religious in nature, and while politics could come up, it could not be central to the discussion. He became unpopular again when he declared what was evident to many by the middle of the 1980s-that the war was unwinnable and would only lead to attrition. He used his weight as a public intellectual to speak to members of the US government, political leaders in El Salvador, leaders of the FMLN, and even Roberto D'Aubuisson - the general who gave the order killing Óscar Romero. In all of his dealings personally and as the representative of the university, he always fulfilled the role of the organic public intellectual and with a central quest to find his idea of truth in the reality of an increasingly volatile El Salvador.

"His life and death set an example that all those who followed him in seeing a need for philosophy could only hope to emulate: "To want to know, to want to possess true knowledge about man and his city, about, in short, himself; to understand this knowledge as critical and operative; to do so with a desire for service, with detachment and liberty; or dedicate his life to this to the ultimate consequences ... these are some of the characteristics of this man who was the critical conscience of his day". (Whitfield 1995, p. 204)

These words Ellacuría spoke of Socrates seem eerily interchangeable between the life and witness of Socrates and of Ellacuría both-we could even suggest Jesus. It seems that, for Ellacuría, philosophy could never be separated from its lived reality. As liberation theologians saw it-the ideas could not be separated from praxis. Ellacuría would even say that the danger of ideology is that it is removed from the reality of the people. As his two great models had-Ellacuría lived and died for the people 
he sought to represent. As Romero and the many other Latin American martyrs in the latter half of the twentieth century, he and his fellow Jesuits were gunned down at their residence at the UCA on 16 November 1989 on the order to "Kill Fr. Ellacuría and leave no witnesses". Just as Socrates had been charged with corrupting the youth of Athens, so the Jesuits became targets for their position to speak out against the violence and repression taking place in the country. As, Ellacuría had said many times in class, he had become the "inconvenient philosopher who paid with his life for the absolute necessity to philosophize", and united himself fully with his crucified people. As he wrote so eloquently in a tense that could almost be interchangeable between first or third person relating to Socrates: "He could not and did not know how to do anything else. An inner spirit encouraged him. He had a vocation. He philosophized by vocation. So much so that he argued that a life without philosophizing was not worth it, and therefore, when asked to stop philosophizing to continue living, he preferred to take the hemlock of his death sentence. He did not want to leave the city, nor stop philosophizing, the two conditions that put him to save his life; they were two indissoluble things for him; he philosophized in his city and for his city, he lived to philosophize, since philosophizing was his life" (Ellacuría [1976] 1998, p. 118).

The Jesuit universities in Central America continue this legacy of Socratic liberation to this day. Indeed, the Jesuit UCA in Managua lists "working to transform unjust structures and situations", and a "preferential option for the poor" as part of the university's values. ${ }^{1}$ These are the same liberationist objectives that Ignacio Ellacuría espoused and that are a part of the Salvadoran UCA's legacy today. The Salvadoran UCA has gone undertaken polls of growing 'neoliberal' development in the region and maintains a place that has been called "the critical conscience of the nation" (Valiente 2015, p. 294). While it is not the solitary voice it was during the civil war-thanks to a widening democracy - it maintains a place of "critical collaboration" with political parties and the private sector (Valiente 2015, p. 295). It is this place of criticism, and the proximity to the popular majorities, which is part of Ellacuría's legacy. Indeed, with death threats being posed against Jesuits at the UCA in Managua, and a growing hostility to open dialogue, we hope that this place of criticism and social transformation is not met with the violence seen in El Salvador in the 1980s. But, the unnerving similarity to the 1980s where the bishop and university rector have been targets to be "wiped out", give cause for concern. ${ }^{2}$ Indeed, as Ellacuría showed by his life, work, and death, taking a stance on the side of the poor and open dialogue can come with a price-we can only hope that this is not another of those times.

Funding: This research received no external funding.

Conflicts of Interest: The author declares no conflict of interest.

\section{References}

Aquino, María Pilar, Kevin F. Burke, and Robert Anthony Lassalle-Klein. 2006. Love That Produces Hope: The Thought of Ignacio Ellacuria. Collegeville: Liturgical Press.

Beirne, Charles J. 1996. Jesuit Education and Social Change in El Salvador. New York and London: Garland Publishing Inc.

Burke, Kevin F. 2000. The Ground Beneath the Cross: The Theology of Ignacio Ellacuria. Washington: Georgetown University Press.

Ellacuria, Ignacio, and Michael Edward Lee. 2013. Ignacio Ellacuria Essays on History, Liberation, and Salvation. Maryknoll: Orbis Books.

Ellacuría, Ignacio. 2000. Filosofía ¿Para Qué? Available online: http:/ /www.uca.edu.sv/facultad/chn/c1170/ filo_pa_que.pdf (accessed on 20 August 2018).

1 UCA Misión, Visión, y Valores. Available online: http:/ /www.uca.edu.ni/index.php/institucion/mision-vision-valores (accessed on 15 August 2018).

2 David Agren, America: The Jesuit Review. Available online: https://www.americamagazine.org/politics-society/2018/06/ 05/jesuits-denounce-threats-seek-protection-nicaraguan-bishop (accessed on 12 July 2018). 
Ellacuría, Ignacio. 1998. Por qué Muere Jesús y por qué le Matan. Available online: http:/ / www.servicioskoinonia. org/relat/125.htm (accessed on 14 August 2018).

Gould, Jeffrey L. 2015. Ignacio Ellacuria and the Salvadorean Revolution. Journal of Latin American Studies 47: 285-315. [CrossRef]

Lee, Michael. 2005. Transforming Realities: Christian Discipleship in the Soteriology of Ignacio Ellacuria; Notre Dame: University of Notre Dame. Available online: curate.nd.edu/downloads/rj430289f7z (accessed on 22 November 2017).

Valiente, Orfilio Ernesto. 2015. The University as Agent of Social Transformation: The Case of the University of Central America in El Salvador. Journal of Catholic Higher Education 34: 281-99.

Whitfield, Teresa. 1995. Paying the Price: Ignacio Ellacuria and the Murdered Jesuits of El Salvador. Philadelphia: Temple Univ. Press.

(c) 2018 by the author. Licensee MDPI, Basel, Switzerland. This article is an open access article distributed under the terms and conditions of the Creative Commons Attribution (CC BY) license (http://creativecommons.org/licenses/by/4.0/). 